\title{
Vertikale drcen på Vestkysten - stor sandopbygning i stedet for sandtab
}

Af ingeniørerne Poul Jakobsen og Claus Brøgger, SIC

Denne artikel er en opfølgning af indlæggene bragt i GeologiskNyt 1/07. Opmålingerne efter 2 år viser, at anvendelse af de vertikale drænrør som kystbeskyttelse har stoppet erosionen syd for Hvide Sande havn. Middelstrandhøjden er hævet signifikant i forhold til Ref-område 1 og Ref-område 2 uden vertikale dræn. Opmålingerne viser endvidere, at der er læsideakkumulation i Ref-område 3 i modsætning til høfder og bølgebrydere, som skaber stor læsideerosion. Samtidig er der sket en betydelig sandopbygning $i$ forkanten af klitten og forstranden $\mathrm{i}$ de drænede områder. Dette har medført forøget sandfygning til baglandet i modsætning til Ref-område 1 og 2, hvor der er stor bølgeerosion. Det er derfor nødvendigt at plante fx hjælme fra klitfoden og 10 - 15 meter ud på stranden, så sandet fastholdes på forstranden.

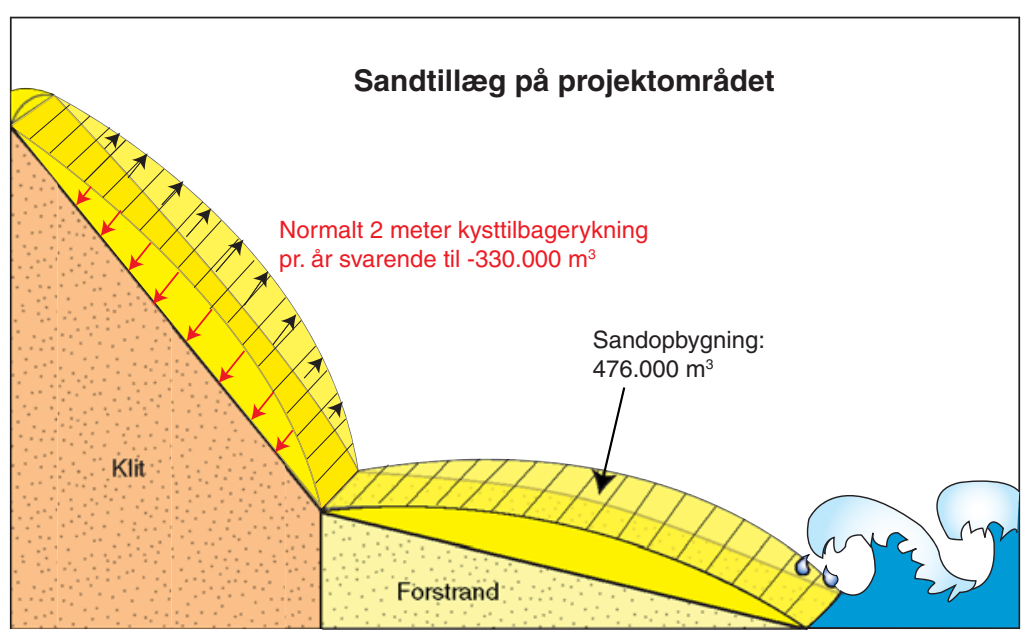

Figuren viser den normale årlige kysttilbagerykning på 2,0 meter i alt 330.000 $\mathrm{m}^{3}$ samt kystopbygningen i forstranden og forkanten af klitten $476.000 \mathrm{~m}^{3} \mathrm{i}$ 2005.(Grafik: UVH modificeret efter udlceg af forfatterne; anvendt i 1/07)

Efter to år og en hård vinter på Vestkysten med ikke mindre end fem storme fra oktober 2006 til 20. januar 2007 har sandtabet på stranden i Rørområde 1 og 2 samt Ref-område 3 kun været $69.000 \mathrm{~m}^{3}$.

\section{Sandopbygning}

Systemet med vertikale dræn giver som tidligere beskrevet læsidetillæg af vasket sand i modsætning til hårde konstruktioner, som giver læsideerosion.

Stormen i marts 2007 ligger efter opmålingen for de første to år og er derfor ikke med i beregningerne.

Strandfodringen på $960.000 \mathrm{~m}^{3}$ ved Søndervig er skyllet i havet, og det vurderes, at havet har taget yderlige ca. $400.000 \mathrm{~m}^{3}$ af klitterne i strandfodringsområdet nord og syd for Søndervig, hvor der er store klitskader.

\section{Søndervig uden drænrør 2005 og 2007}

Sandfodring ved Søndervig d. 5. juli 2005 efter strandfodring med $960.000 \mathrm{~m}^{3}$ sand på stranden. Vandstand: $+45 \mathrm{~cm}$. (Foto: P. Jakobsen d. 05-07-2005)

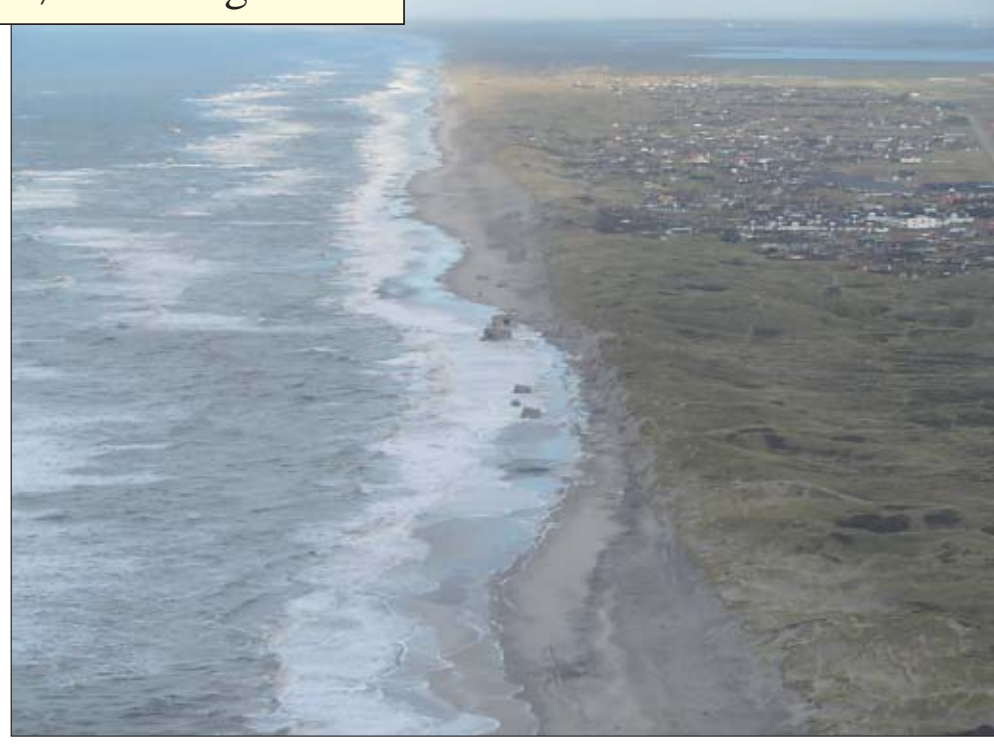

Søndervig d. 16 januar 2007 efter en investering på 42,0 mio. kr. i strandog revlefodring. Strandfodringen er skyllet $i$ havet, og havet har taget ca. $400.000 \mathrm{~m}^{3}$ af klitterne. Vandstand: $+50 \mathrm{~cm}$. (Foto: P. Jakobsen) 


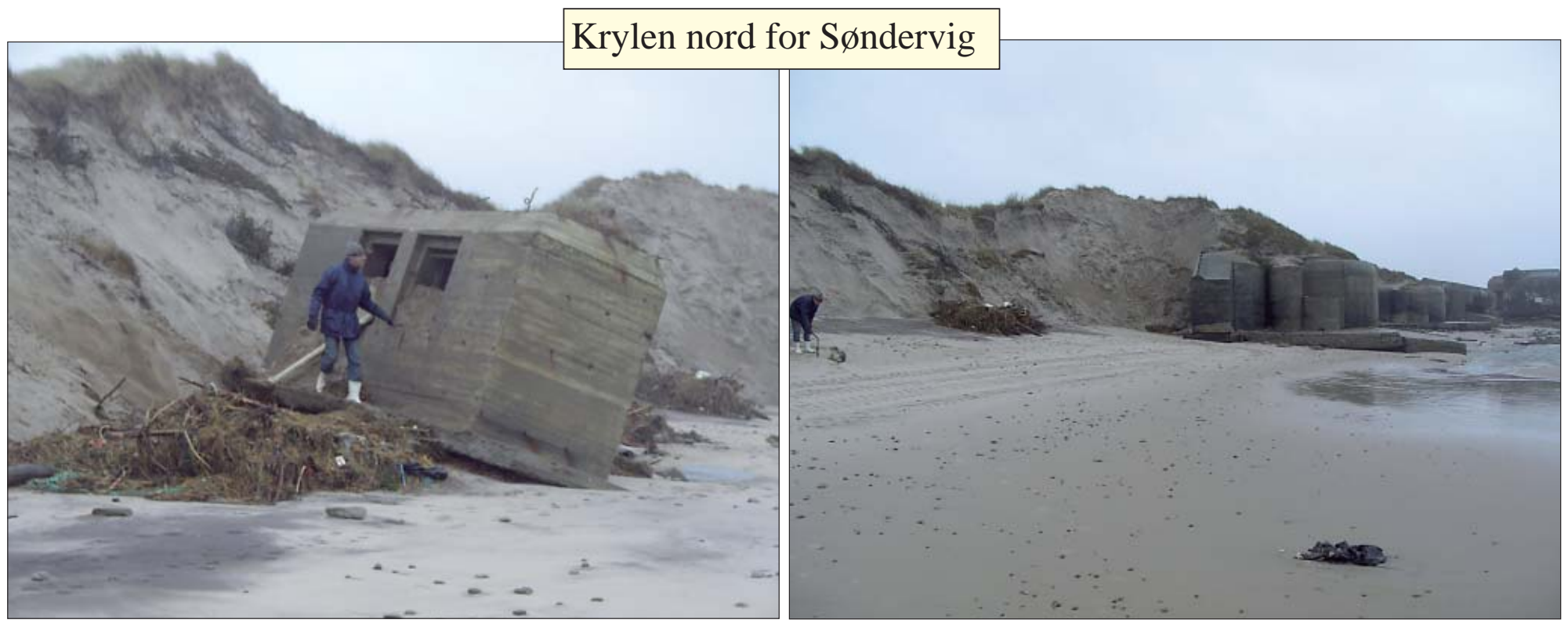

Bunkerne velter ud af klitterne efter vinterens storme i 2006/07, som vi så ved Søndervig i 2005. Strandfodringen på $960.000 \mathrm{~m}^{3}$ er skyllet $i$ havet. (Foto: P. Jakobsen)

Strand- og revlefodringen ved Søndervig har kostet ca. 42 mio. kr. incl. skråningsbeskyttelsen, som kostede ca. 8,0 mio. kr.

Som beskrevet i GeologiskNyt 1/07 har systemet med de vertikale drænrør stoppet erosionen i læside-erosionsområdet syd for Hvide Sande havn.

Samtidig er der sket en sandopbygning fra klittoppen og ud til kystlinen på 476.000 $\mathrm{m}^{3}$, så den samlede effekt er $806.000 \mathrm{~m}^{3} \mathrm{i}$ det første år.

Hvis sandmængden i forstranden beregnes med baggrund i den nye beregningsmetode baseret på fastlåste referencelinier, er sandtillægget $411.000 \mathrm{~m}^{3}$ og en samlet effekt på $741.000 \mathrm{~m}^{3}$ i det første år.

\section{Vinddata}

Som vi ser i figuren nedenfor til venstre, er vindhastigheden på Hvide Sande væsentligt lavere end vindhastigheden på Torsminde og Blåvandshug. Dette skyldes vindmålerens placering på rensningsanlægget inde bag klitterne i Hvide Sande. Vindmåleren viser således 7 - $10 \mathrm{~m} / \mathrm{sek}$ for lidt ved vestlige vindretninger.

Det er derfor nødvendigt at interpolere vinddata for Torsminde og Blåvandshug.

Data for middelvinde i Torsminde ses på figuren nederst til højre - målingerne stammer fra d. 13.-14. januar.

Efterfølgende har vi kvalitetsvurderet KDI's (Kystdirektoratets) vinddata fra Slusen i Hvide Sande, men disse vinddata var også signifikant afvigende fra Torsminde og Blåvandshug, idet vindmåleren var nedslidt og til slut blæste ned i stormen d. 19.- 20. januar 2007.

Med baggrund i vinddata fra Blåvandshug og Hvide Sande er der registreret følgende storme på Vestkysten i vinteren 2006/07:

Det er en fejl at der ikke blev opsat en vindmåler i projektområdet i forbindelse med projektstart i januar 2005.

\begin{tabular}{|l|c|}
\hline \multicolumn{1}{|c|}{ Dato for storme } & Maksimal vandstand \\
\hline 27. oktober, 2006 & $1,54 \mathrm{~m}$ \\
\hline 1. januar, 2007 & $1,75 \mathrm{~m}$ \\
\hline 11.-12. januar 2007 & $2,14 \mathrm{~m}$ \\
\hline 14. januar, 2007 & $1,78 \mathrm{~m}$ \\
\hline 19.-20. januar, 2007 & $1,78 \mathrm{~m}$ \\
\hline
\end{tabular}

Opmåling på stranden blev påbegyndt d. 22. januar og afsluttet d. 25. januar 2007. Alleopmålinger er udført af Carl Bro A/S

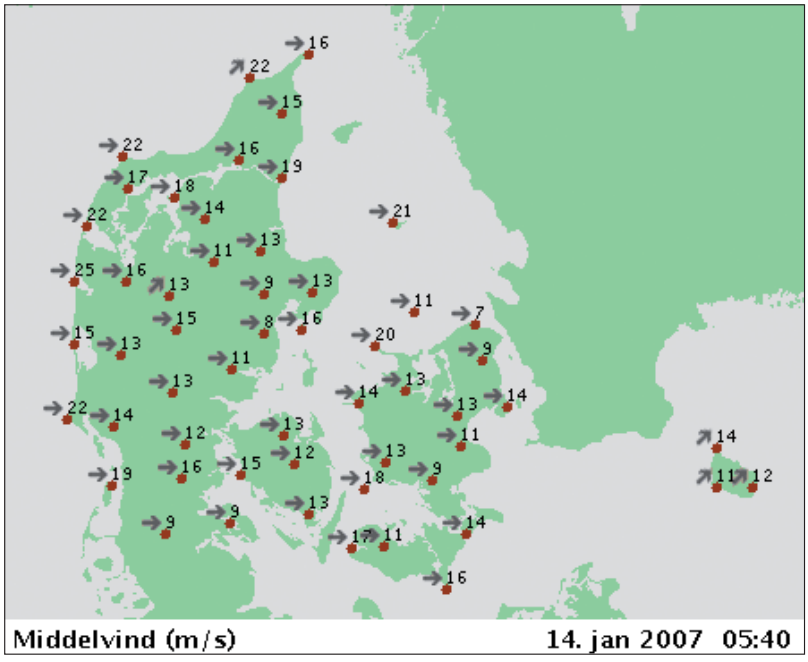

Vindhastighedsdata fra d. 14. januar, 2007. (Grafik: gengive med tilladelse fra DMI)

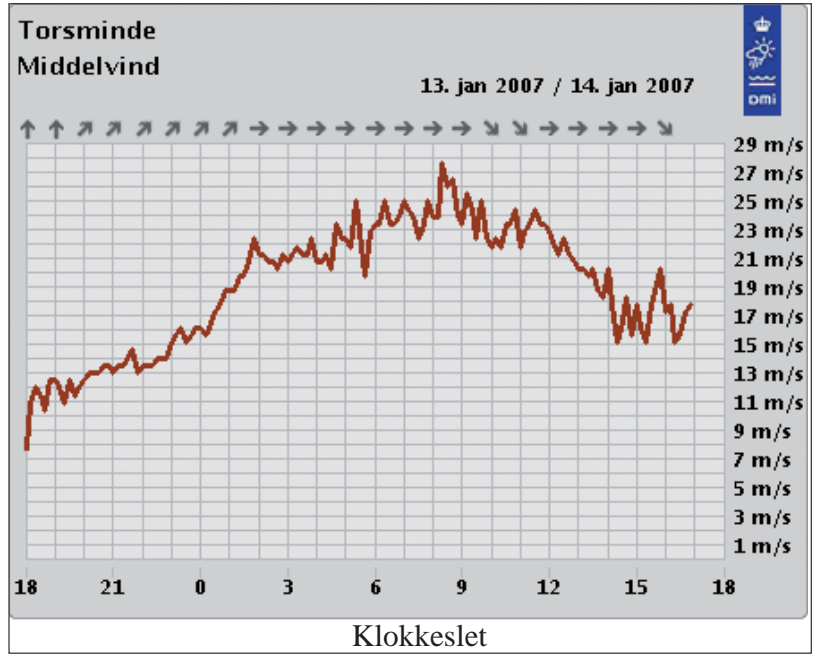

Middelvind - data fra Torsminde fra d. 13.-14. januar, 2007. (Grafik: gengivet med tilladelse fra DMI) 


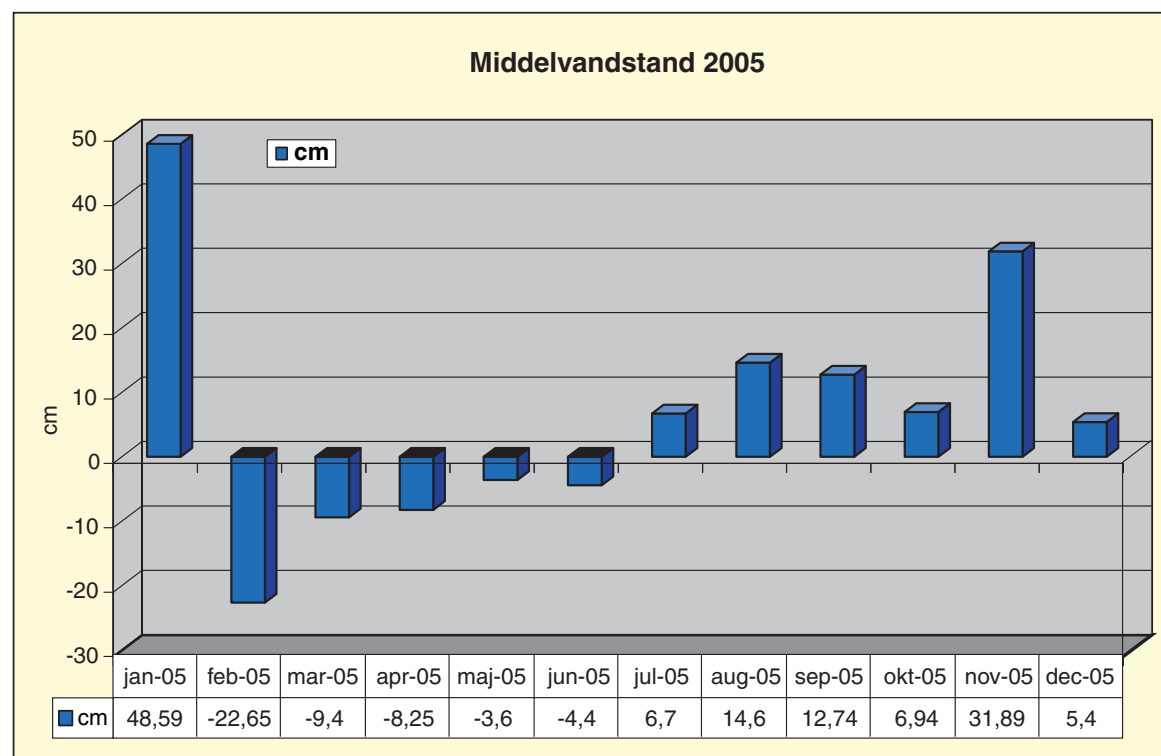

Middelvandstand 2006 samt januar 07

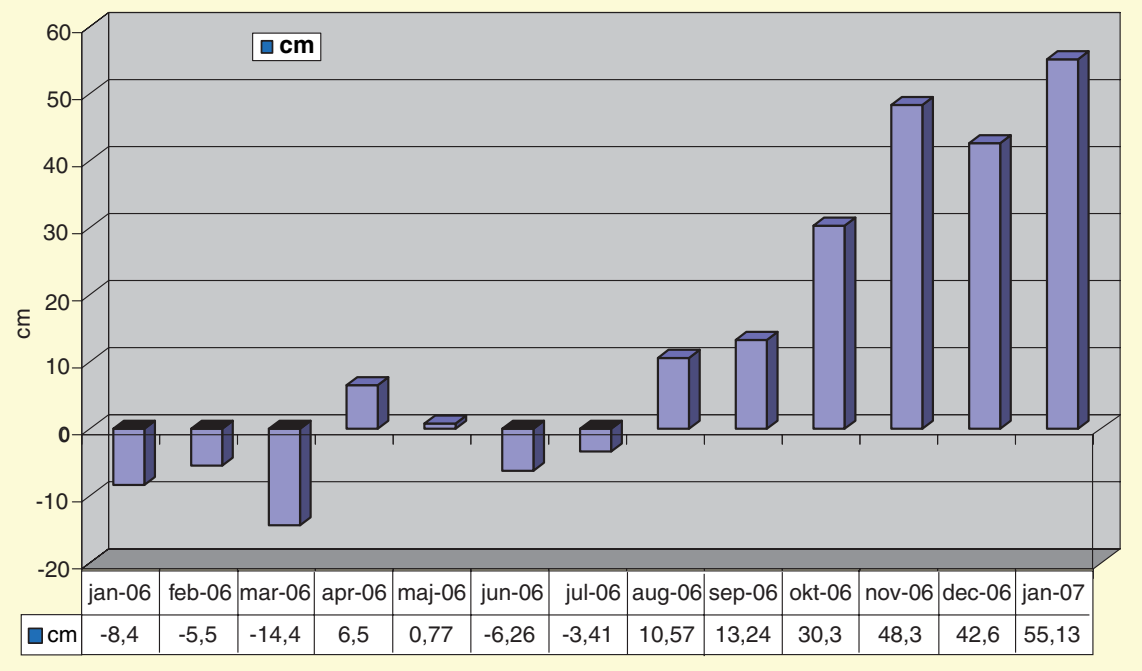

Figurerne viser middelvandstanden månedsvis i henholdsvis 2005 og i 2006 samt januar 2007. (Grafik: UVH modificeret efter udlag af forfatterne)

\section{Geologisk tidsskala}

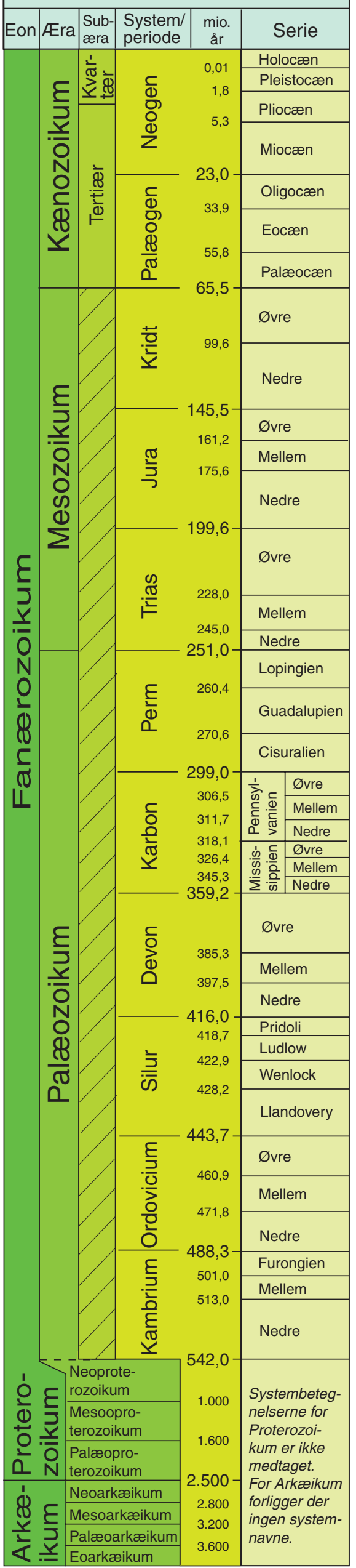

\section{Vandstand.}

Middelvandstanden på Vestkysten lå i $2005+6,55$ cm over DVR 90, som det ses på figuren øverst på denne side. (DVR = Dansk Vertikal Referance er et nyindført højdesystem, der er baseret på det seneste præcisionsnivellement - det betegnes "Нøjdesystem DVR 90”).

Middelvandstanden på Vestkysten lå i $2006+9,53 \mathrm{~cm}$ over DVR 90.

Middelvandstanden var i stormperioden fra d. 20. oktober 2006 til d. 20. januar 2007 $+54,5 \mathrm{~cm}$ over DVR 90.

SIC-systemet blev således testet under forhold, som svarer til den globale vandstandsstigning over 100 år.

Man ser tydeligt den forhøjede middelvandstand i månederne oktober, november, december i 2006 samt januar i 2007 på ovenstående figur. Tilsvarende ser man lavere værdier i 2005. 


\section{Bølger}

Som det ses på nederste illustration på figuren til højre på denne side, viser bølgemåleren nogle voldsomme bølgehøjder i januar 2007, hvilket indikerer, at vejret har været ekstremt hårdt på Vestkysten i vinteren 2007.

Bølgedata er registreret over perioder af 20 minutter på x-aksen. Data er levet af KDI

De højeste målinger på over 16 meter (markeret med en stjerne på figuren) forekommer dog ikke realistiske og anses derfor for at være fejlagtige.

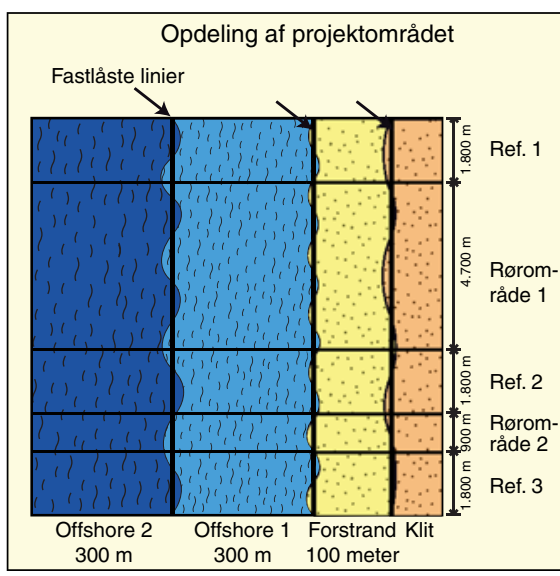

Klitten er defineret fra kote +4 i DVR 90 til klittop. Forstranden er fra kote +4 i klitfod og 100 m ud mod havet. Kote +4 i klitfoden er fastlåst til opmålingen i januar 2005, hvor anleggget er etableret. Offshore 1 er 300 meter bred og fastlåst til referencelinien $i$ kote +4 januar 2005. Offshore 2 er 300 meter bred og fastlåst til Offshore 1. (Grafik: UVH modificeret efter udlceg af forfatterne; anvendt i 1/07)
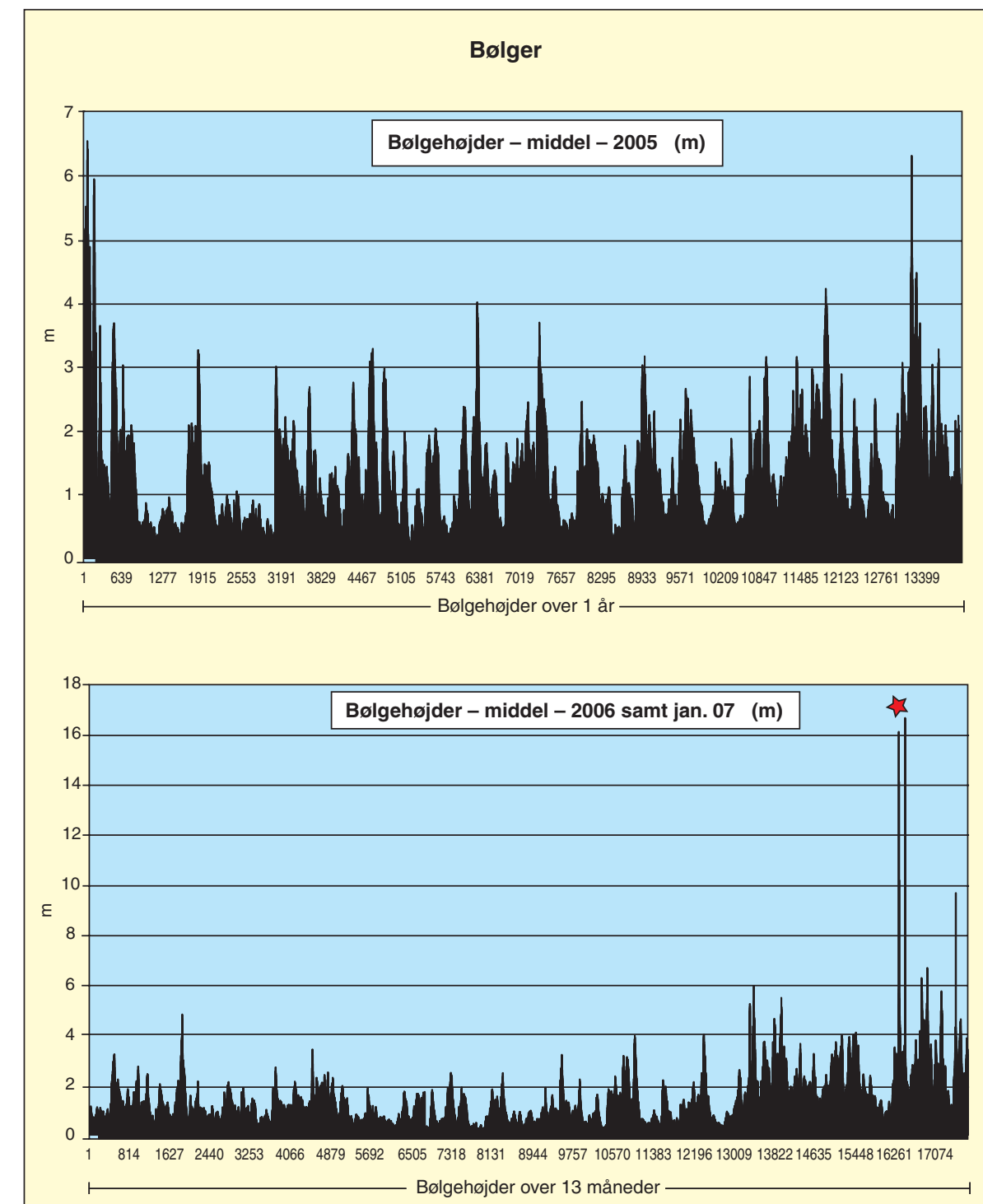

Bølgehøjder målt i henholdsvis 2005 og 2006 samt januar 2007. Bemcerk målingerne markeret med en stjerne - disse forekommer urealistiske og kasseres derfor. (Grafik: UVH modificeret efter udlceg af forfatterne)

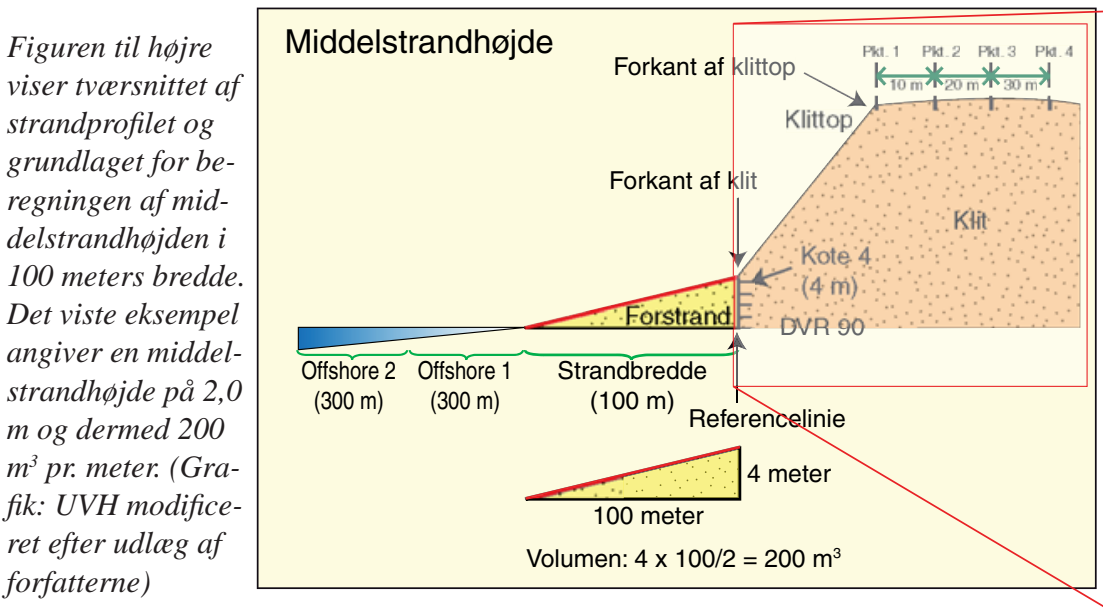

Figuren til højre viser forkanten af klitten samt målepunkterne på klittoppen, så udviklingen i klitten kan beregnes. I det første år var der en akkumulation i forkanten af klitten i de drcenede områder på $20 \mathrm{~m}^{3}$ pr. meter (ses på figuren nederst s. 13). I de drcenede områder er der en opbygning på toppen med $10-15 \mathrm{~m}^{3} \mathrm{pr}$. år (se teksten side 15), og den samlede opbygning i klitten er således $30-35 \mathrm{~m}^{3}$ pr. år. (Grafik: UVH modificeret efter udlceg af forfatterne)

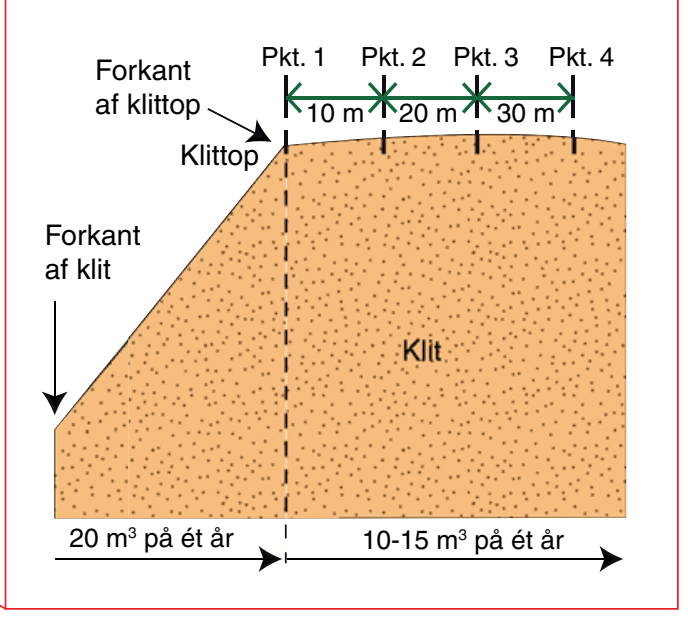

\begin{tabular}{|c|c|}
\hline \multicolumn{2}{|c|}{ Beregningseksempel } \\
\hline $\begin{array}{l}\text { Opbygning i forkanten af klitten } \\
\text { (i de drænede områder): }\end{array}$ & $20 \mathrm{~m}^{3}$ pr. år \\
\hline Opbygning på toppen af klitten: & $10-15 \mathrm{~m}^{3} \mathrm{pr}$. år \\
\hline Samlet opbygning i klitten pr. år: & $30-35 \mathrm{~m}^{3} \mathrm{pr}$. år \\
\hline
\end{tabular}




\section{Design}

Målet med projektet er at bygge en 70$100 \mathrm{~m}$ bred sandstrand foran klitterne i et balanceprofil (teoretisk: Et profil der ikke eroderes). Der sættes max. 11 moduler i de enkelte rækker. Modulerne er neddykkede $25 \mathrm{~cm}$ i stranden.

Middelstrandhøjden skal være større end 1,3 m. Når middelstrandhøjden er større end $1,3 \mathrm{~m}$, ser man nemlig ikke haverosion i klitterne i stormsituationer. Når middelstrandhøjden er 1,3 m, har man en buffer på $130 \mathrm{~m}^{3}$ pr. meter langs stranden (jævnfør figuren på foregående side). Kystlinien skal være så lige som muligt for at opnå de bedste resultater.

\section{Resultat efter 2 år}

Opmålingerne viser, at middelstrandhøjden. Som beskrevet nederst på side 12 er middelstrandhøjden den vigtigste faktor, når man skal evaluere styrken på en strand (modstandsdygtigheden).

Middelstrandhøjden (figuren øverst på siden), viser med et enkelt tal den gennemsnitlige strandhøjde i 100 meters bredde fra klitfoden og ud mod havet i de enkelte områder.

Det samme tal angiver samtidig antallet af $\mathrm{m}^{3} \mathrm{i}$ forstranden, når man ganger tallet med 100 .

Opmålingerne viser, at middelstrandhøjden er større end 1,3 m i begge rør områder samt Ref-område 3, hvor der er læsidetillæg med vasket sand.

I modsætning hertil er middelstrandhøjden faldet i Ref-område 1 fra 1,06 meter til 73 cm., og i Ref-område 2 fra 1,35 m til 29 $\mathrm{cm}$.

Den oprindelige strand er således borteroderet i Ref-område 2, som var det stærkeste område i januar 2005.

Samtidig ser vi en forøgelse af middelstrandhøjden i Ref-område 3. Dette skyldes aflejringen af vasket sand fra Rørområde 2, og vi kan hermed se, at strande med vertikale dræn giver læsideakkumulation i modsætning til høfder og bølgebrydere, som giver stor læsideerosion.

Denne proces foregår også inde i Rørområde 1 , men vil først give udslag i Ref-område $2 \mathrm{i}$ løbet af nogle år.

\section{Klitudvikling}

Når middelstrandhøjden bliver signifikant højere i de drænede områder, fyger sandet fra forstranden meget lettere ind i baglandet og medfører en forstærkning af klitterne, som vi uddyber nærmere på de efterfølgende sider.

I Ref-område 1 er erosionen fra januar 2006 til januar 2007 17,1 m³. I Ref-område 2 er erosionen $21,6 \mathrm{~m}^{3} \mathrm{pr}$. meter, som det ses på figuren nederst på siden.

Modsætningsvis er erosionen i Rørområde 1 og Rørområde 2 henholdsvis $9,9 \mathrm{~m}^{3}$ og $9,8 \mathrm{~m}^{3}$.

Det vil sige, at kliterosionen i forkanten

\begin{tabular}{|r|r|c|c|c|c|c|}
\hline \multicolumn{5}{|c|}{ Middelstrandhøjde - perioden 2005-2007 } \\
\hline
\end{tabular}

Middelstrandhøjden er beregnet fra klitfoden i kote 4,0 og 100 meter ud mod havet, som vist på foregående side. (Grafik: UVH modificeret efter udlceg af forfatterne)

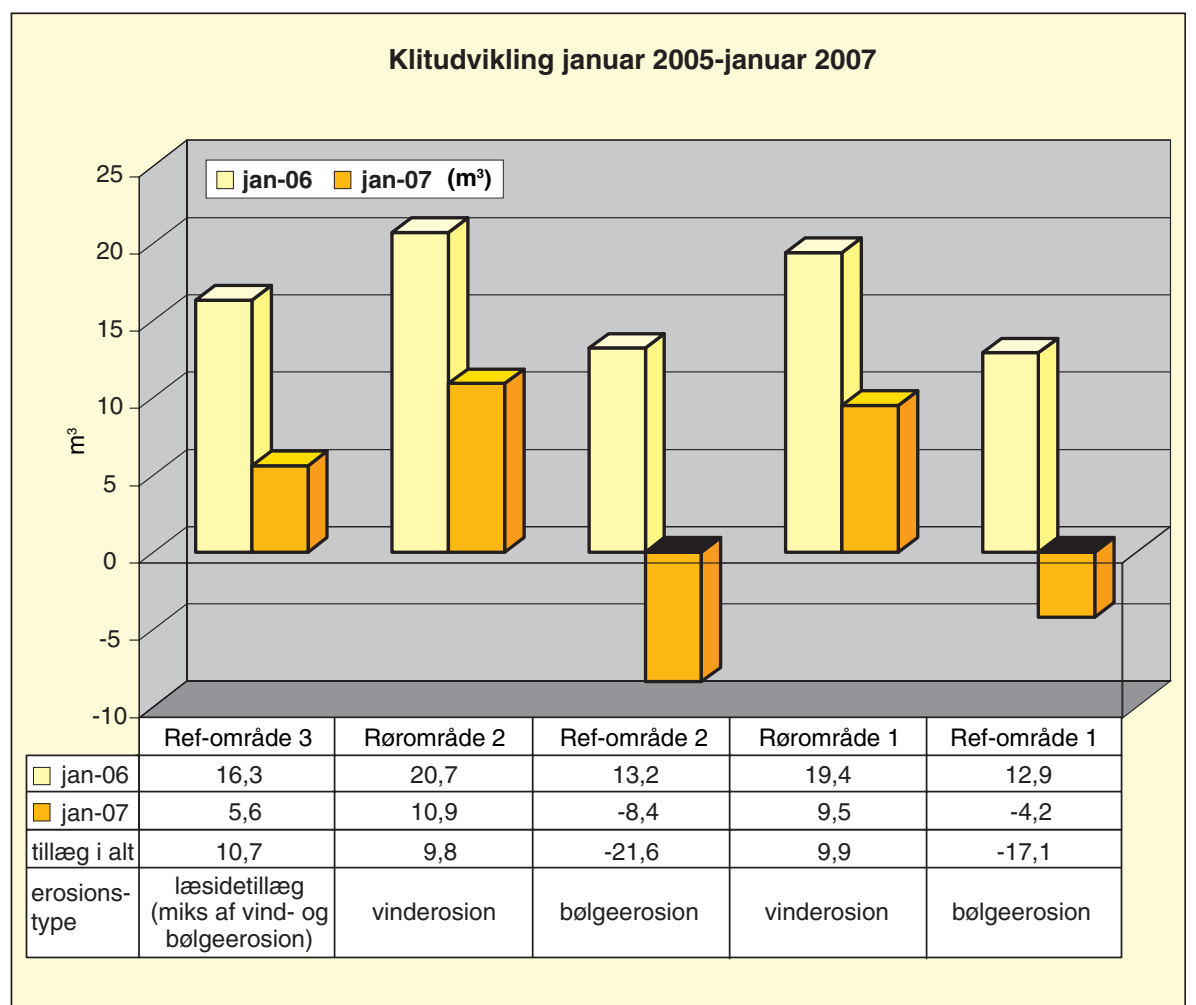

Figuren viser klitudviklingen $i$ henholdsvis januar 2006 og januar 2007. I rørområderne er det primert vinderosionen, der dominerer, mens det er bølgeerosionen, der dominerer i referenceområderne. (Grafik: UVH modificeret efter udlceg af forfatterne)

af klitterne er dobbelt så stor i Ref-område 1 og Ref-område 2 i forhold til de drænede rørområder.
I rørområderne er det primært vinderosion, der dominerer, mens der i referenceområderne primært er dominans af 


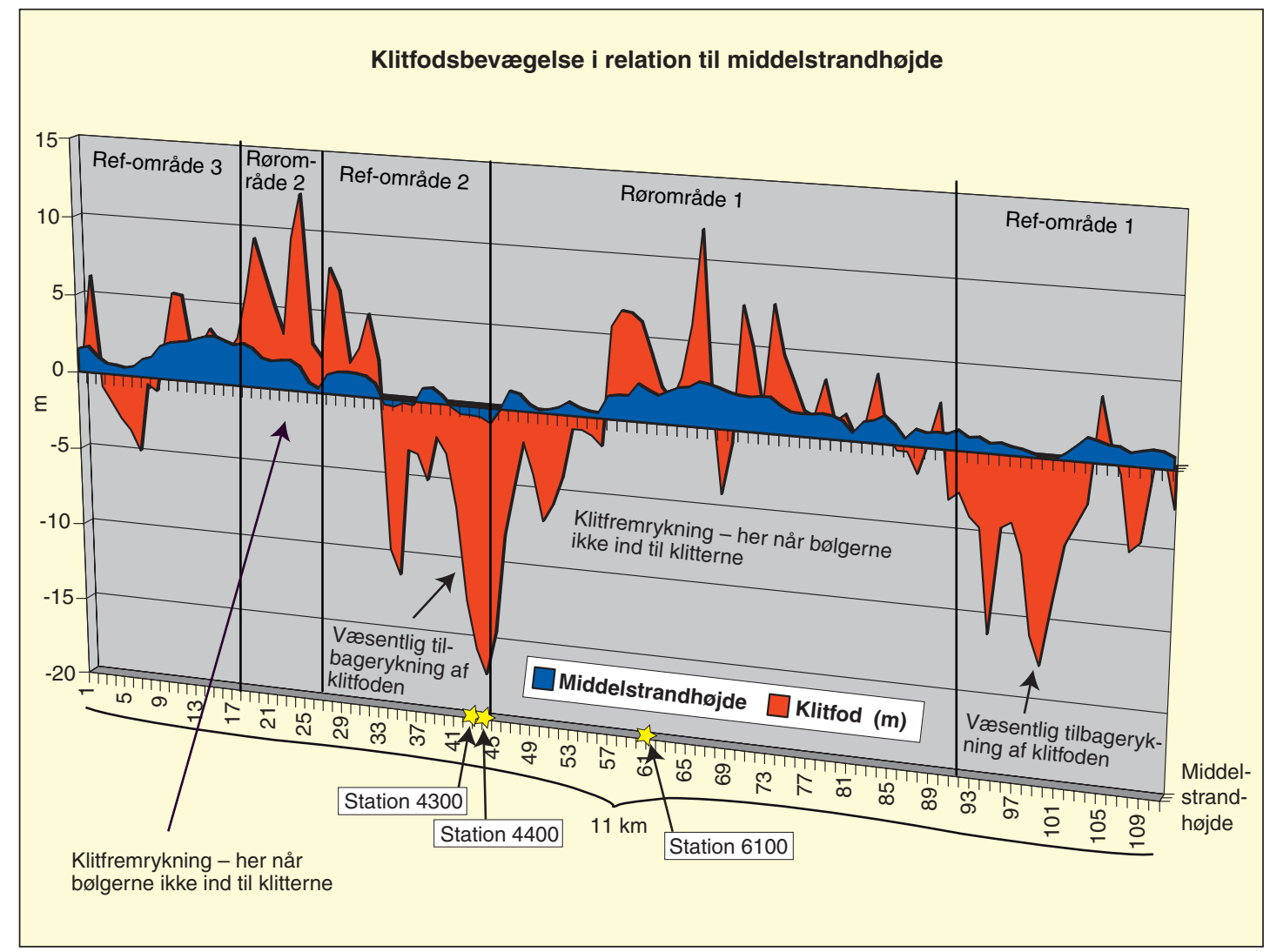

Figuren viser klitfodsbevegelsen sammenstillet med middelstrandhøjden. (Grafik: UVH modificeret efter udlceg af forfatterne)

bølgeerosion, som vi ser det på figurerne på denne side.

Klitfoden er rykket op til 12,5 meter tilbage i Referenceområde 1 og op til 17 meter tilbage i Referenceområde 2, hvor havet har været dybt inde i klitterne.

\section{Klitfodsbevægelse}

Figuren øverst på denne side viser ændringerne i klitfoden sammenholdt med middelstrandhøjden. Man ser tydeligt, at klitfoden rykker frem i de drænede områder (for eksempel i Rørområde 1 og Rørområde 2), mens der er bølgeerosion i områderne med lav middelstrandhøjde (for eksempel i Refområde 1 og 2).

Bølgeerosionen fører materialerne tilbage til havet, mens sandet går tabt inde i baglandet ved vinderosion.

Der er således en væsentlig forskel på erosionen i forkanten af klitterne i henholdsvis rørområderne og i referenceområderne.

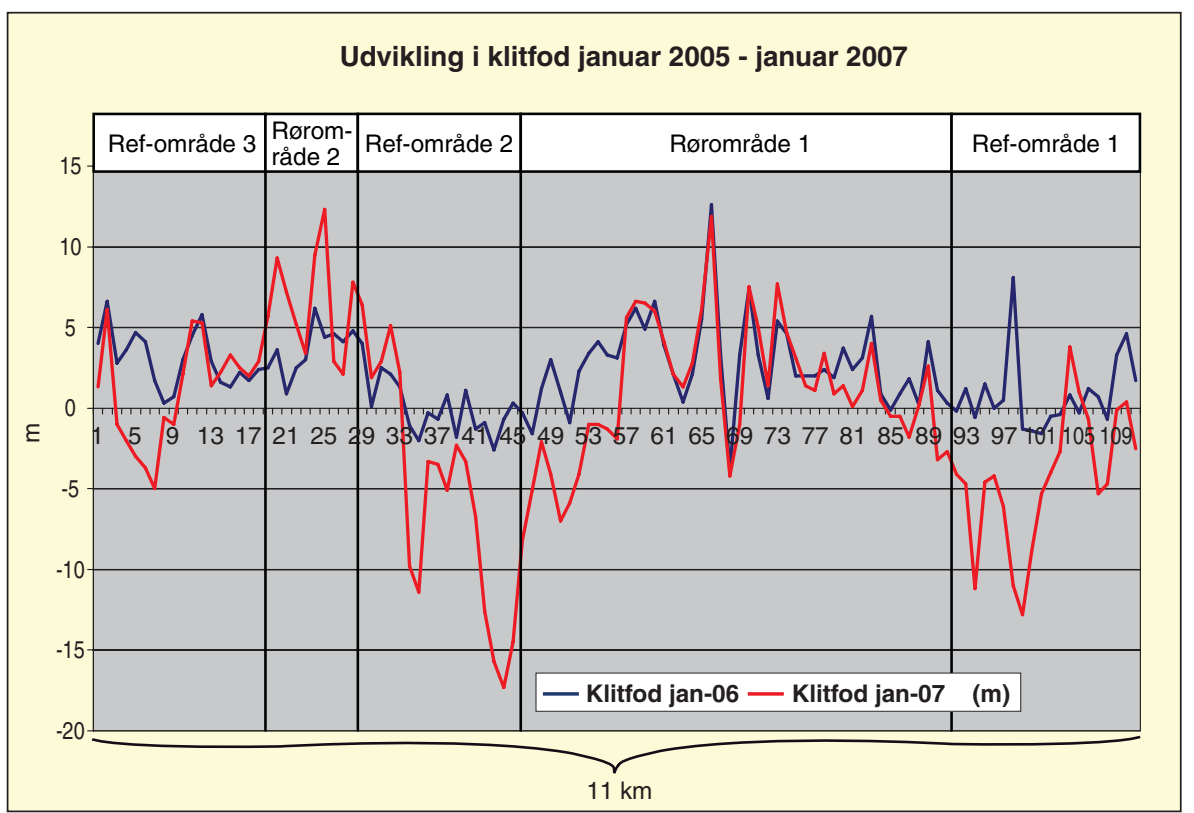

Vind- og bølgeerosionens indflydelse på reference- og rørområderne. (Grafik: UVH modificeret efter udleg af forfatterne) 


\section{Vinderosion}

I forbindelse med drænede strande er det nødvendigt at fokusere på vinderosionen i forstranden.

I det første år registrerede vi en opbygning af sand på forkanten af klitten på ca. 20 $\mathrm{m}^{3} \mathrm{i}$ de drænede områder.

Disse $20 \mathrm{~m}^{3}$ er borteroderet af vinden i forstranden og blæst op i forkanten af klitten. Efterfølgende har vi målt, at klitterne i de drænede områder hæver sig på toppen med $90-120 \mathrm{~cm}$ på 2,5 år i et 30 meter bredt bælte.

Dette svarer til 27 - $36 \mathrm{~m}^{3}$ over 2,5 år eller 10 - $15 \mathrm{~m}^{3}$ pr. meter om året.

Vi kan således se, at vinderosionen i forstranden er mindst $30-35 \mathrm{~m}^{3}$ pr. meter pr. år eller ca. $100 \mathrm{~m}^{3}$ over 3 år.

Vi skal således se nærmere på to forhold. For det første sænkes forstranden i de drænede områder ca. 100 cm i løbet af 3 år, hvis stranden er 100 meter bred.

Erosion i forstranden er således ikke bare erosion, men der skal skelnes mellem vinderosion i de drænede områder og bølgeerosion i Ref-område 1 og Ref-område 2, hvor forstranden reelt er borteroderet af bølgerne.

For det andet er det imidlertid kun de finkornede materialer, som fyger op i klitterne, mens ral og sten forbliver i forstranden.

Vinderosionen er således en væsentlig faktor, når vi taler om, at materialerne bliver grovere i forstranden, når strandene drænes.

Det er et faktum at vinden blæser ca. 100 $\mathrm{m}^{3}$ sand pr. meter over 3 år op i klitterne.

\section{Sigteprøver fra forstrand og klit}

Materialeprøverne i stranden og klitterne, der er illustreret i tabellen nederst på denne side, viser følgende:

- $33 \%$ af materialerne i forstranden er grovere end 4,0 $\mathrm{mm}$ i korndiameter

- $39 \%$ af materialerne i forstranden er grovere end 2,0 mm i korndiameter.

- $45 \%$ af materialerne i forstranden er grovere end 1,0 mm i korndiameter.

Samtidig viser prøverne i klitterne, at:

- $98 \%$ af sandet i klitterne har en korndiameter som er mindre en $1,0 \mathrm{~mm}$

- $84 \%$ har en korndiameter som er mindre end $0,5 \mathrm{~mm}$

Sigteanalyser af sandet i klitterne viser, at det sand, som fyger op i klitterne, er meget finkornet og har en korndiameter, som fortrinsvis er mindre en $0,5 \mathrm{~mm}$.

Vi kan således se, at den samlede mængde sand, som er sorteret af vinden i forstranden, er den dobbelte mængde i forhold til de sandmængder, vi finder i klitterne.

Den vindsorterede sandmængde pr. meter i forstranden er således ca. $200 \mathrm{~m}^{3} \mathrm{pr}$. meter over 3 år.

Vi kan derfor konstatere, at materialerne i forstranden bliver grovere og grovere over

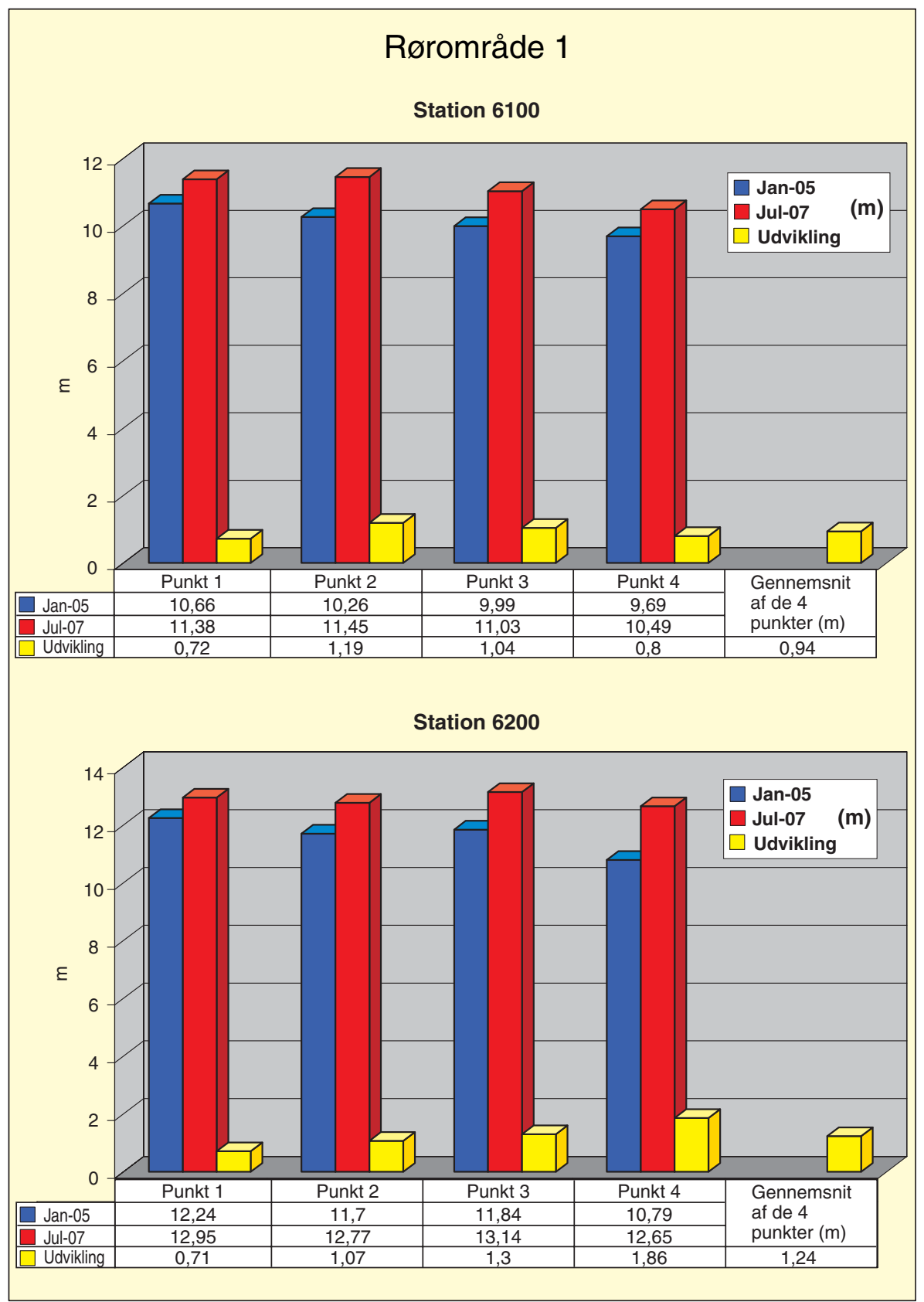

De to figurer viser data for sandopbygning i klitten i Rørområde 1 fra Station 6100 og Station 6200 (lokaliteterne for disse ses på figuren side 14, og placering af de 4 punkter på side 12). (Grafik: UVH modificeret efter udlceg af forfatterne)

Sigteprøver fra forstrand og klit

\begin{tabular}{|l|r|r|r|r|r|r|r|r|r|l|} 
Kornstørrelse mm & $<0,063$ & 0,13 & 0,25 & 0,5 & 1 & \multicolumn{1}{|c|}{2} & \multicolumn{1}{|c|}{4} & \multicolumn{1}{c|}{8} & 16 & 31,5 \\
\hline 2500 Rør 8 (\%) & 0 & 0,1 & 12,7 & 43 & 54,3 & 58,5 & 62,8 & 84,5 & 84,5 & 100 \\
\hline 2500 Rør 7 (\%) & 0 & 0 & 8,5 & 35,9 & 51,7 & 59 & 64,7 & 84,2 & 84,2 & 100 \\
\hline 2600 Rør 7 (\%) & 0 & 0,1 & 10,8 & 40,9 & 57,6 & 66,7 & 74,5 & 94,1 & 94,1 & 100 \\
\hline 2600 Rør 6 (\%) & 0 & 0,1 & 13,2 & 59 & 72,9 & 76,6 & 79,4 & 91,6 & 91,6 & 100 \\
\hline 2700 Rør 7 (\%) & 0 & 0,1 & 8,5 & 40 & 54,5 & 61,8 & 67,8 & 95,1 & 95,1 & 100 \\
\hline 2700 Rør 6 (\%) & 0 & 0 & 4,1 & 25,8 & 37,9 & 44,7 & 50,9 & 89 & 89 & 100 \\
\hline 2650 Klitfod (\%) & 0 & 0,2 & 16 & 65,4 & 82,7 & 88,1 & 91 & 100 & & \\
2700 Klitfod (\%) & 0 & 0 & 4,1 & 27,1 & 43,3 & 59,9 & 76,1 & 100 & & \\
\hline 2700 Forkant klit (\%) & 0 & 0 & 20,7 & 88,9 & 99,7 & 100 & & & & \\
2700 Bagkant klit (\%) & 0 & 0,1 & 14 & 78,2 & 96,6 & 100 & & & & \\
2700 Bagkant klit (\%) & 0,1 & 0,3 & 18,6 & 83,7 & 99,1 & 100 & & & & \\
\hline
\end{tabular}

Tabellen viser data for sigteprøver fra forstranden og klitten. Tallene er vist i procent. 


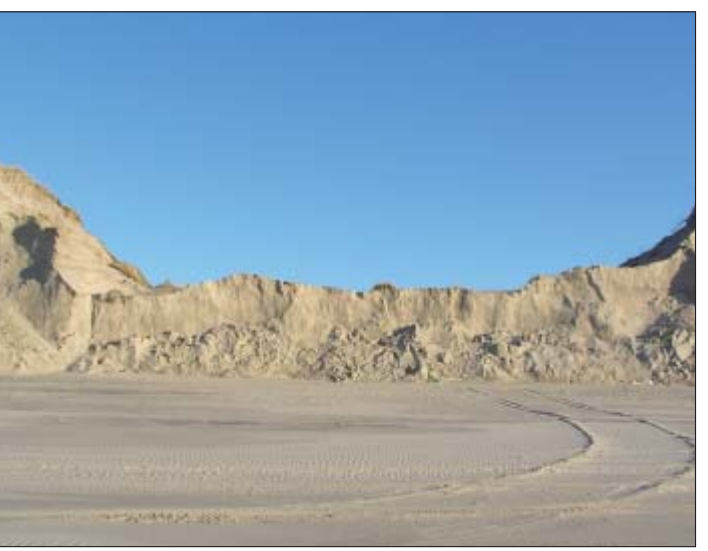

I Ref-område 2 er klitfoden rykket 17 meter tilbage - herved er klitten helt forsvundet. (Foto: Poul Jakobsen - anvendt i GN1/07)

tid, og stranden får således en væsentligt bedre dræningsevne generelt, idet K-værdien (den hydrauliske ledningsevne) forøges signifikant i de drænede områder på grund af vindsortering i forstranden.

Sandet fra Nordsøen, som bruges til sandfodring på Vestkysten, har ifølge KDI typisk en korndiameter mellem 0,25 mm og $0,5 \mathrm{~mm}$, men sandet er reelt ubrugeligt til strand- og revlefodring ifølge amerikanske eksperter (NBPC, 2000 Hawaii), og man bør derfor nøje overveje, om det i fremtiden er denne metode, man bør anvende.

Der er imidlertid meget stor forskel på vindsorteringen i Rørområderne 1 og 2 og Ref-område 1 og 2, hvor middelstrandhøjden er meget lav.

Det ser man tydeligt i de to følgende illustrationer. For eksempel ser man i figuren til højre fra Ref-område 2, at højden af klittoppen falder i begge stationer.

Til gengæld bliver klittoppen højere i Station 6100 og 6200 i Rørområde 1 (figuren øverst på foregående side).

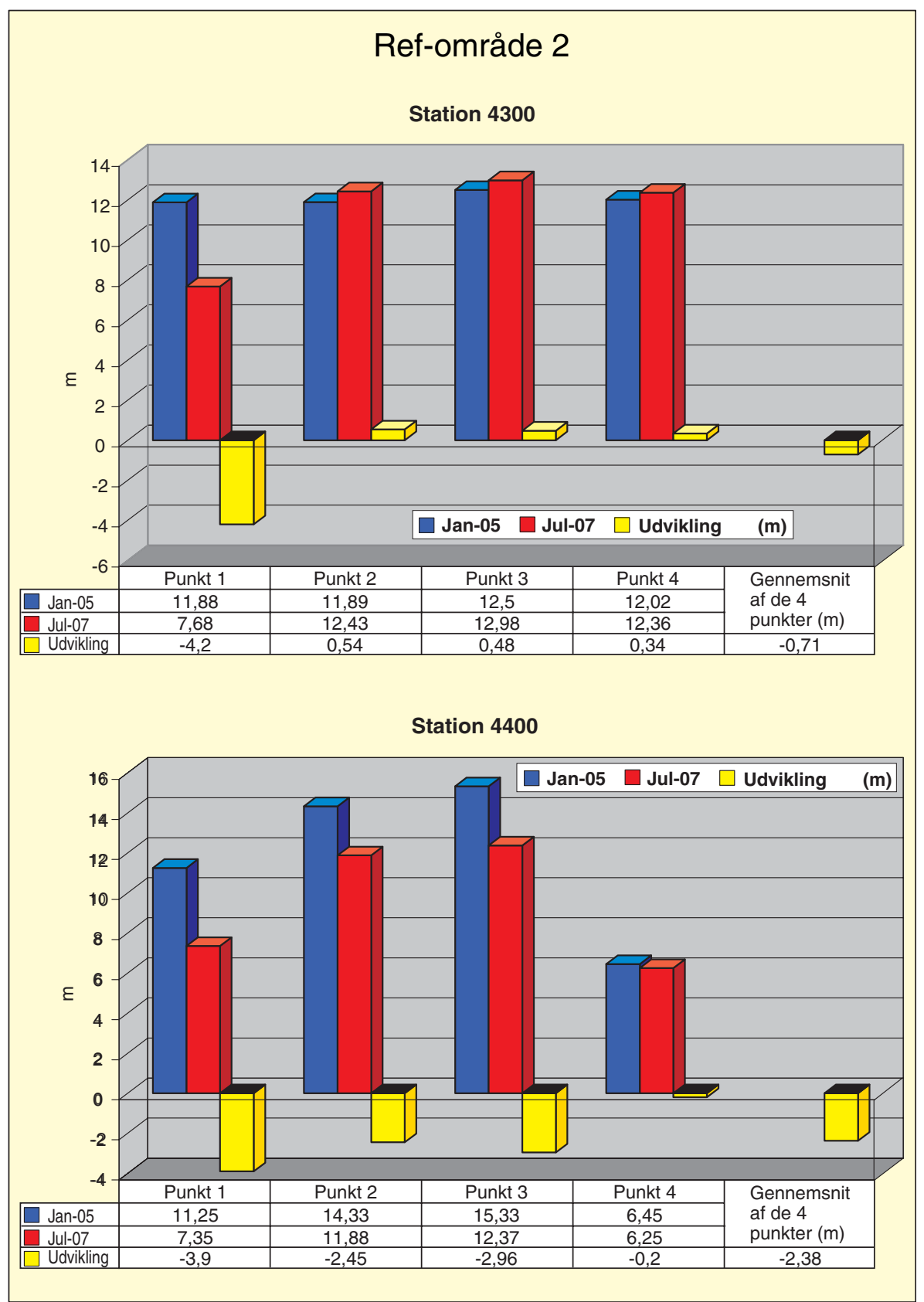

De to figurer viser data for udviklingen på toppen af klitten i Ref-område 2 fra Station 4300 og Station 4400 (lokaliteterne for disse ses på figuren øverst på side 14, og placering af de 4 punkter på side 12). (Grafik: UVH modificeret efter udlceg af forfatterne) 


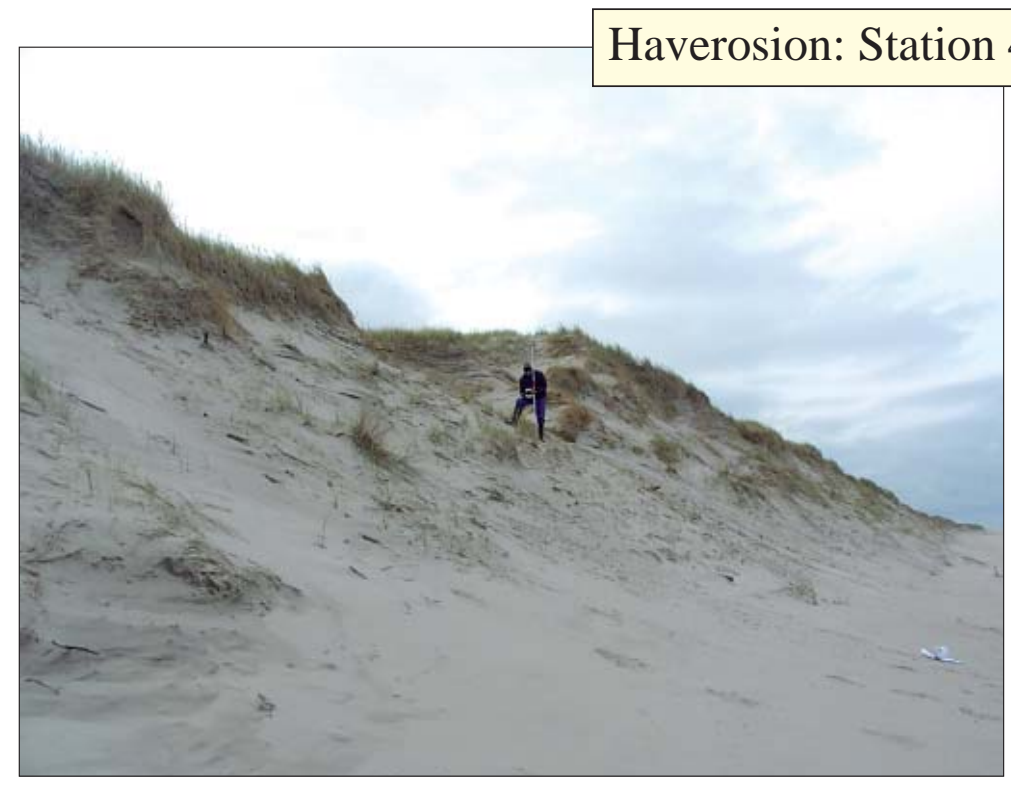

Haverosion. Allan Christensen fra Carl Bro A/S står her i forkanten af klitten, som tidligere var toppunktet på klitten. (Foto: P. Jakobsen)

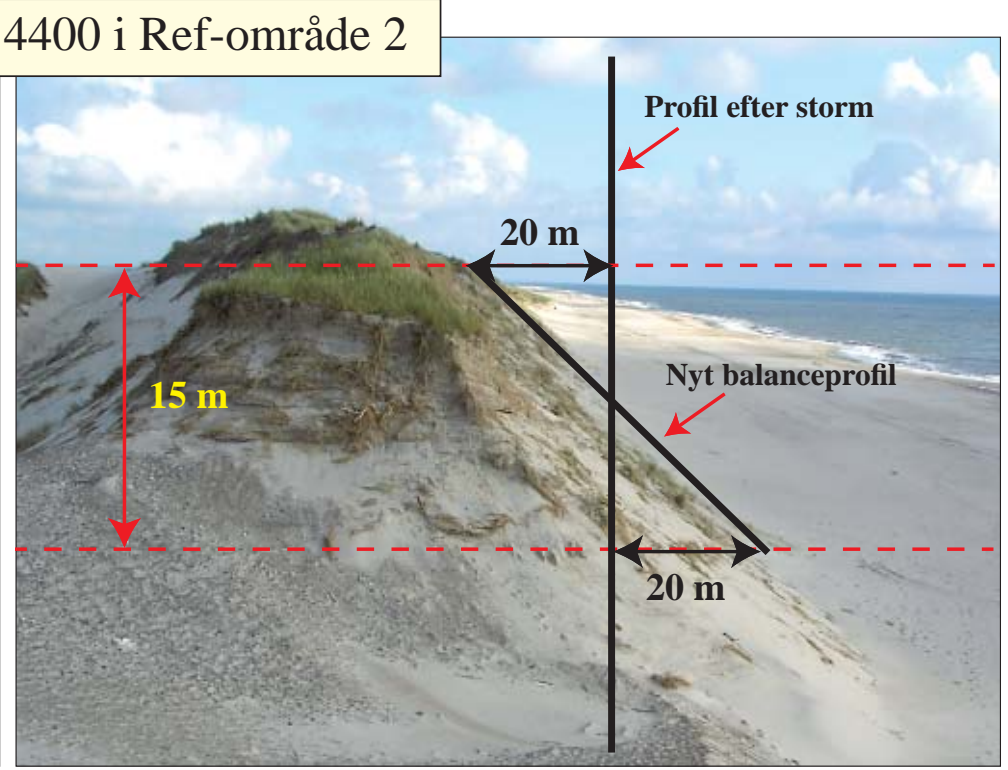

Haverosion. Stregerne markerer hhv. profilet efter stormen og det nye balanceprofil. Toppen af klitten er faldet ned på stranden. (Foto: $P$. Jakobsen)

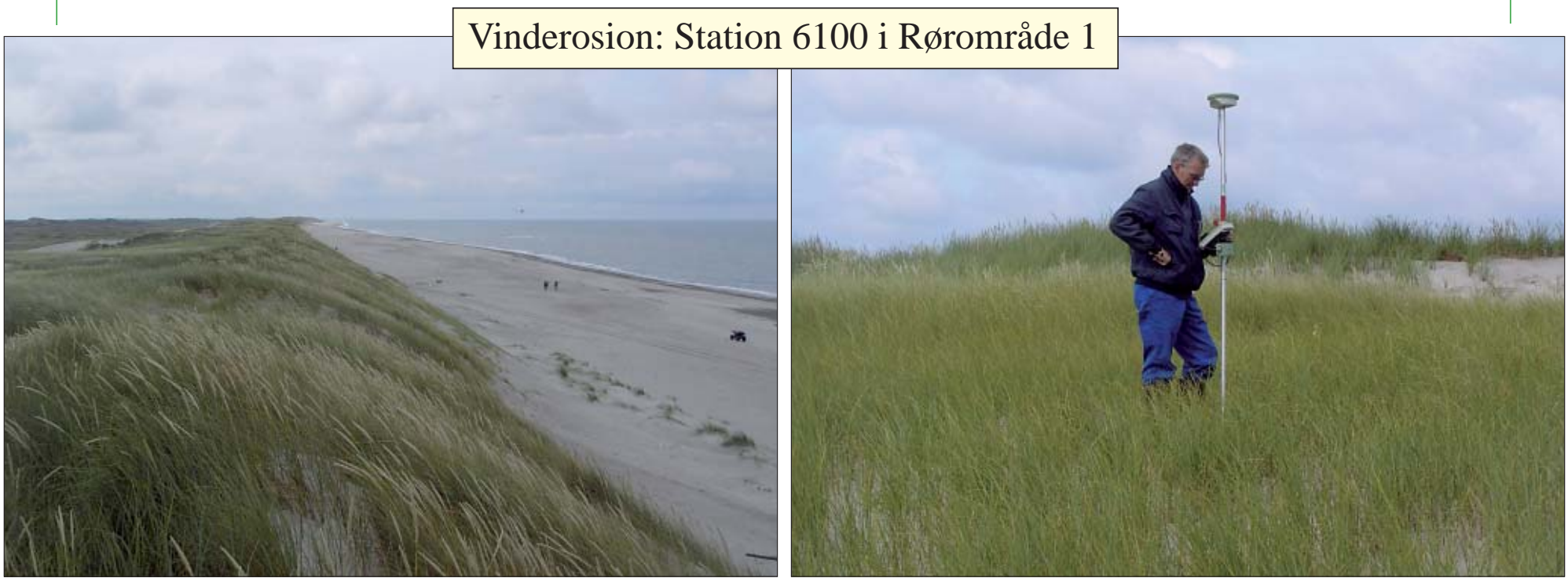

Vinderosion. Der finder klitopbygning sted i de drœenede områder. Klitterne er hœvet i de drænede områder mellem $90 \mathrm{~cm}$ og $120 \mathrm{~cm}$ over 2,5 år i de 4 målepunkter på toppen af klitterne, idet en del af sandet fra forkanten af klitten er føget langere ind i klitsystemet (ca $10 \mathrm{~m}^{3}$ pr. meter). (Foto: P. Jakobsen)
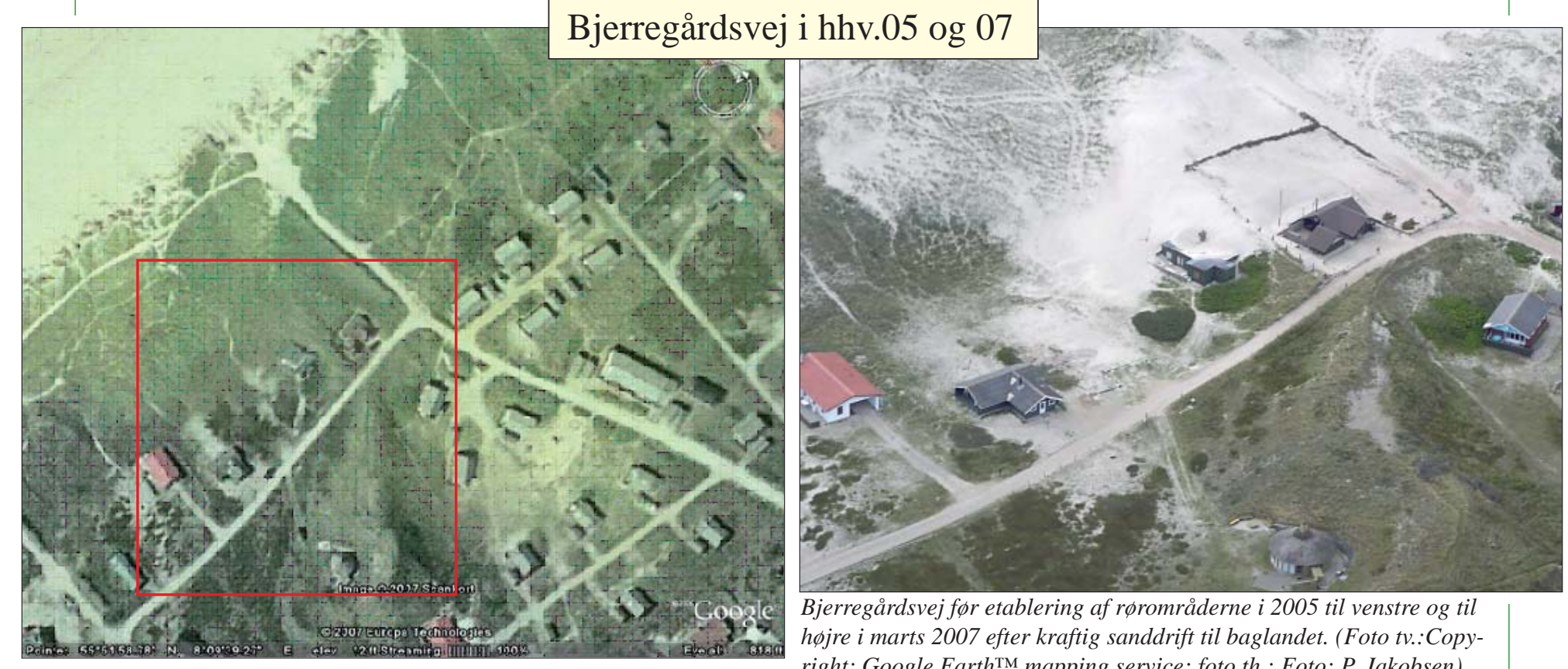

Bjerregårdsvej før etablering af rørområderne i 2005 til venstre og til højre i marts 2007 efter kraftig sanddrift til baglandet. (Foto tv.:Copyright: Google Earth ${ }^{\mathrm{TM}}$ mapping service; foto th.: Foto: P. Jakobsen) 


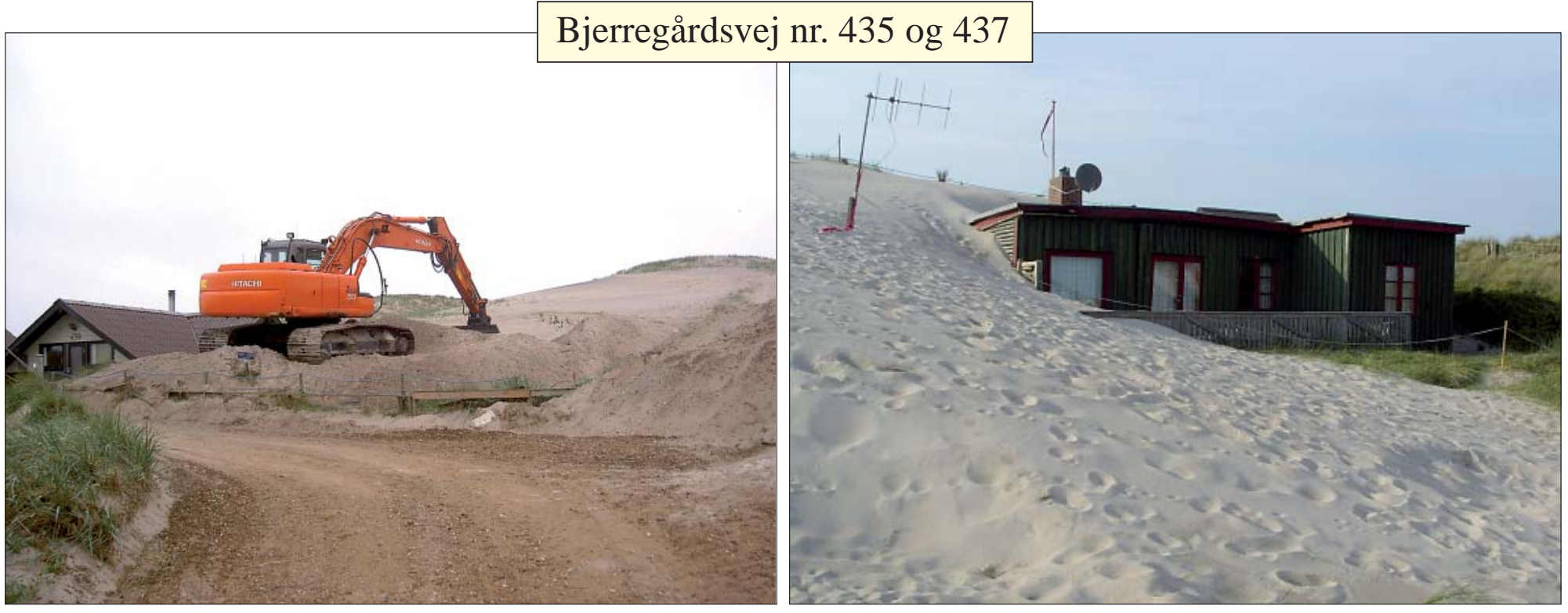

Flere ejendomme er begravede i sand på grund a fsanddriften til baglandet - her er det to huse på Bjerregårdsvej. (Foto: P. Jakobsen)

Principskitsen viser et løsningsforslag på vinderosionsproblemet, så man undgår tilsanding af husene bagved klitten. Der skal plantes hjcelme eller marehalm eller lignende i klitfoden. (Grafik: UVH modificeret efter udlceg af forfatterne)

\section{Løsning}

Løsningen på vinderosionsproblemet er at plante hjælme eller lignende fra klitfoden og 10-15 meter ud i forstranden, så sandet fastholdes i forstranden og specielt i klitfoden, så kysten er bedre sikret specielt i højvandssituationer med storm eller orkan.

\section{Forstranden}

Erosionen har i vinteren 2006/2007 kun været ca. 69.000 m $^{3}$ Rørområde 1 og Rørområde 2 samt Ref-område 3, hvor der er læsidetillæg med vasket sand.

Analyserne viser, at erosionen i Rørområde 1 og Rørområde 2 primært er vinderosion, så sandet er føget ind i baglandet og er ikke gået tabt til havet i modsætning til materialerne, som er taget af havet i Refområde 1 og Ref-område 2.

Figuren og tabellen på side 19 viser, at kystprofilet ikke er forstejlet i projektperioden. Samtidig ser man, at de store erosionsmængder fra Ref-område1 og Ref-område 2 ikke genfindes ude i Offshore 1 efter vinterens voldsomme storme. Storme skaber således ikke et reservoir af sand ude i havet. Det borteroderede sand forsvinder således ud af projektområdet ved kraftige storme.

Figuren viser tillceg/erosion i ref- og rørområderne i januar 2006 og 2007. (Grafik: UVH modificeret efter udlceg af forfatterne)

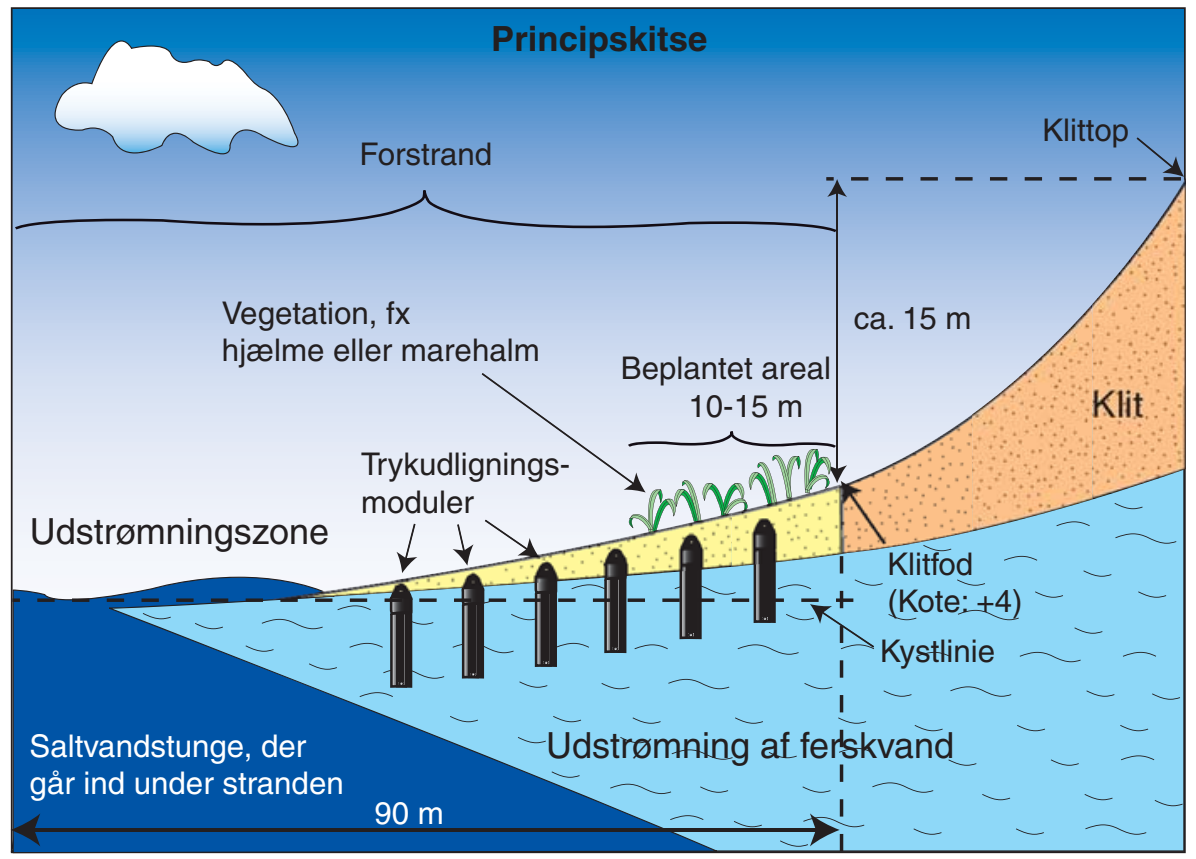

Forkant af klit samt $100 \mathrm{~m}$ fra klitfod mod havet

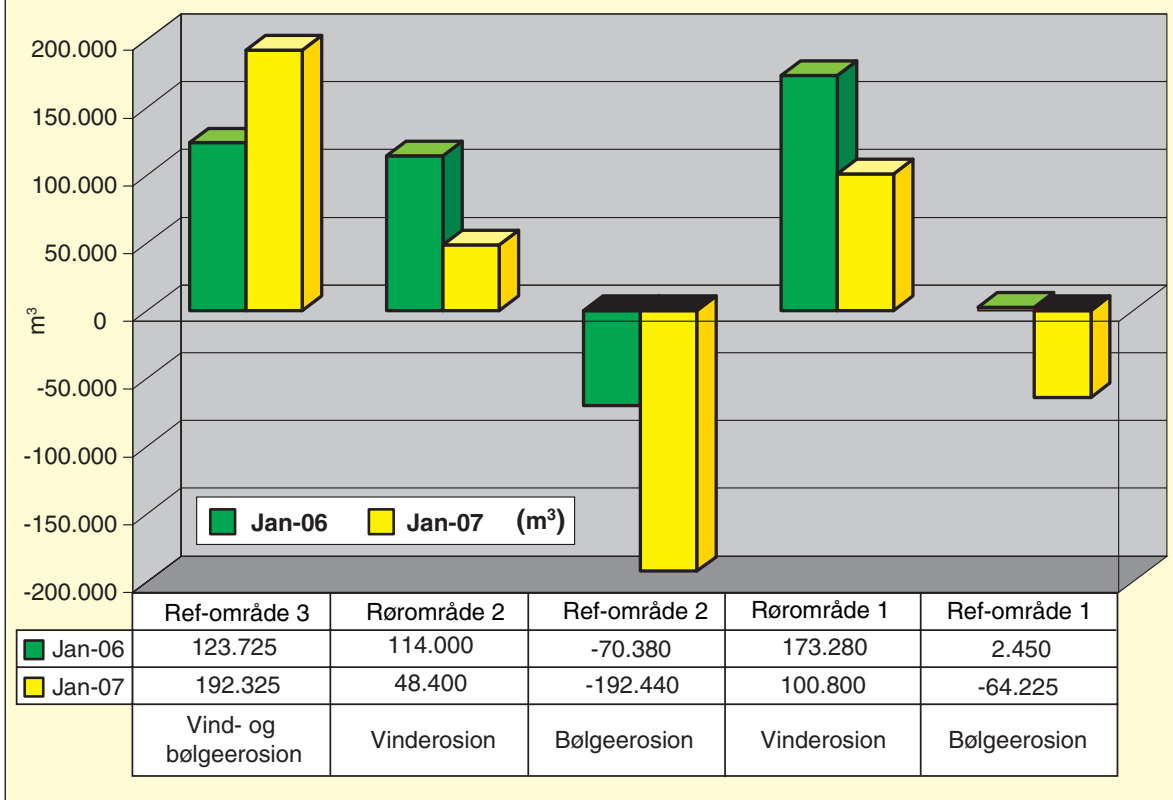


Beskaffenheden af havbunden skal ses i et meget større perspektiv, og vi har vist gennemsnitsværdierne for hele strækningen på 11,0 km i tabellen på denne side.

Analyserne i tabellen viser, at profilet i Offshore 1 har en stigende tendens og er blevet hævet i løbet af 2 år med ca. 9 cm - dette er ikke er relateret til de voldsomme storme i vinteren 2006/07.

\section{Konklusion}

Anvendeligheden af de vertikale drænrør er nu testet i et scenario svarende til den globale vandstandsstigning om 100 år, idet middelvandstanden var over $50 \mathrm{~cm}$ i perioden fra d. 20. oktober 2006 til d. 20. januar 2007.

I samme periode blev Vestkysten ramt af 5 voldsomme storme med middelvindhastigheder på op til $27 \mathrm{~m} / \mathrm{sek}$. Fire af disse storme ramte den jyske vestkyst mellem d. 1. og 20. januar 2007.

Analyserne viser, at haverosionen i klitterne er stoppet i Rørområderne 1 og 2 samt i den nordlige del af Ref-område 3, hvor der er læsidetillæg med vasket sand.

Dette skyldes, at middelstrandhøjden i de drænede områder er blevet forøget signifikant, efter at rørområderne er blevet drænet.

Bufferen foran klitterne i 100 meters brede på $411.000 \mathrm{~m}^{3}$ har været stor nok til at modstå 5 hårde storme fra ultimo oktober 2006 til d. 20. januar 2007, hvor storm nr. 4 i januar måned 2007 ramte den jyske vestkyst.

Den samlede erosion i Rørområde 1 og Rørområde 2 samt Ref-område 3 har kun været $69.000 \mathrm{~m}^{3}$ i vinteren 2006/07. Der er primært tale om vinderosion i rørområderne, så sandet er føget ind i baglandet. I modsætning hertil har der været stor bølgeerosion i Ref-område 1 og Ref-område 2, hvor havet

Udvikling i Offshore 1, januar 2005 - januar 2007

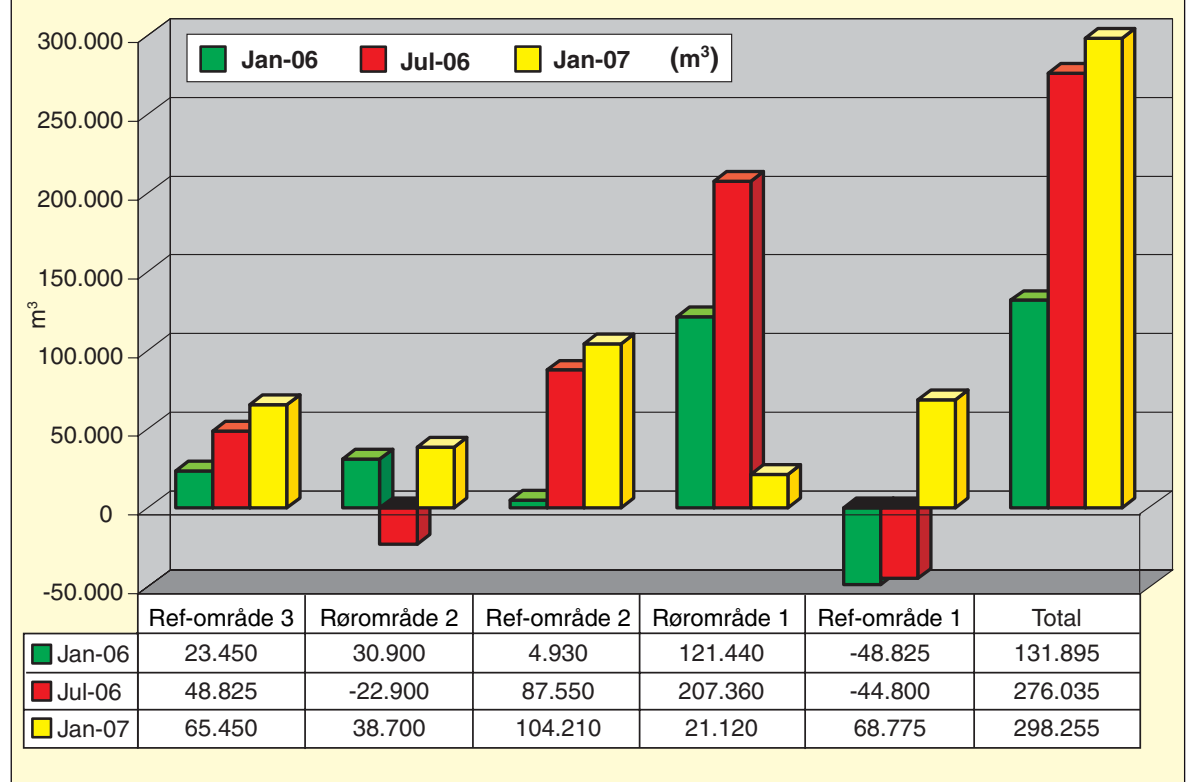

Udvikling i offshore 1 (se figuren øverst til venstre side 12). Hele strcekningen er ca. $11 \mathrm{~km}$ lang og 300 m bred. (Grafik: UVH modificeret efter udlag af forfatterne)

\begin{tabular}{|l|r|r|r|r|r|c|}
\hline \multicolumn{7}{|c|}{ Udviklingen i havbunden Offshore 1 og $2 \mathrm{i} \mathrm{m}^{3}$ pr. meter } \\
& apr-05 & juli-05 & okt-05 & jan-06 & juli-06 & jan-07 \\
\hline Offshore 1 & 1,44 & 9,57 & 24,84 & 11,80 & 24,91 & 27,21 \\
\hline Offshore 2 & 3,54 & 5,01 & 8,23 & $-4,59$ & $-5,84$ & 1,47 \\
\hline
\end{tabular}

\begin{tabular}{|c|c|c|c|c|c|c|}
\hline \multicolumn{7}{|c|}{ Udviklingen i havbunden Offshore 1 og $2 \mathrm{i} \mathrm{cm}$} \\
& apr-05 & juli-05 & okt-05 & jan-06 & juli-06 & jan-07 \\
\hline Offshore 1 & 0,48 & 3,19 & 8,28 & 3,93 & 8,30 & 9,07 \\
\hline Offshore 2 & 1,18 & 1,67 & 2,74 & $-1,53$ & $-1,95$ & 0,49 \\
\hline
\end{tabular}

Tabellen viser erosion/tillag i Offshore 1 og 2 for den fulde strcekning på 11,0 km i en bredde af 2 × 300 meter ude i havet. Øverst ses udviklingen i $\mathrm{m}^{3}$ pr. meter og nederst den gennemsnitlige hævvning eller scenkning af havbunden $i \mathrm{~cm}$.

har taget mere end $250.000 \mathrm{~m}^{3}$ på en $3,5 \mathrm{~km}$ lang strækning, som svarer til $70 \mathrm{~m}^{3} \mathrm{pr}$. meter, selvom der er strandfodret med ca. 2,0 mio. $\mathrm{m}^{3}$ sand over 10 år umiddelbart nord for Ref-område 1. og revlefodret 700 meter ned i Ref-område 1 i projektperioden.

Der er ikke konstateret sandbølger i projektområdet, og målinger offshore viser, at kystprofilet ikke er forstejlet, men hæver sig med stigende tendens.

Billedmonitorering ved Søndervig viser, at sandfodring nr. 2 i 2005 på $960.000 \mathrm{~m}^{3}$ skyllede i havet i samme tidsrum, og det vurderes, at kliterosionen nord og syd for Søndervig har været ca. $400.000 \mathrm{~m}^{3}$ samme periode,

Den samlede erosion i Søndervig-projektet har således været ca. $1.360 .000 \mathrm{~m}^{3}$ i projektperioden. Sandtabet i de drænede områder og Ref-område 3 med vasket sand var kun $69.000 \mathrm{~m}^{3}$, som ligger i baglandet.
Et lignende forsøg med en sandfodring på $100.000 \mathrm{~m}^{3}$ ved Søndervig i 2004 fejlede også, da sandet var skyllet i havet efter en måned; desuden tog havet yderligere $400.000 \mathrm{~m}^{3}$ af klitterne i januarstormen 2005.

\section{Forslag}

Det anbefales, at der plantes hjælme/marehalm fra klitfoden og 10 meter ud mod havet i de drænede områder, så man undgår sandtab til baglandet med ødelæggelser til følge.

Desuden foreslås det, at der etableres $20 \mathrm{~km}$ ved Søndervig, så SIC-systemet kan sammenlignes direkte med sand- og revlefodring i stor målestok. Opmåling i klitarealerne ved Søndervig er baseret på flyopmåling, så man får en bedre monitorering og et bedre værktøj til at undgå sanddriftsskaderne i baglandet. 